\title{
Foster Care Independent Living Services: Youth Perspectives
}

\author{
Christopher G. Petr
}

\begin{abstract}
Emerging adulthood is a phase in the life course recently identified by developmental theorists. For youth in foster care, recent federal legislation in the United States has engendered new programs, typically called independent living programs, to help them become successful adults. This qualitative study reports the findings of interviews with a diverse sample of 27 current and former foster youths in a Midwestern state, focusing on the quantity and quality of independent living services received. The youths reported hopeful expectations and plans for their futures, widespread support for postcustody benefit programs, mixed opinions about the utilization and effectiveness of existing independent living programs, significant educational delays associated with frequent placements while in out-of-home custody, and strong attachments to families of origin.
\end{abstract}

D evelopmental theorists have recently articulated the need to recognize a phase of life termed early adulthood or emerging adulthood (Arnett, 2000; Settersten, Furstenberg, \& Rumbaut, 2005). This theoretical development is comparable to the "discovery" and conceptualization of adolescence as a distinct life phase in the early 1900s. A new category is deemed necessary because of increasing evidence that most young people do not achieve economic and psychological autonomy as early as previous generations. For example, according to United States census data, $18 \%$ of youth at age 20 and $69 \%$ of young adults at age 25 were married in 1970, compared to $5 \%$ at age 20 and $33 \%$ at age 25 in 2000 (Fussell \& Furstenberg, 2005). Internationally, this prolonged period of transition to adulthood-including later age at leaving home, extended period of education, and later age for first marriage and having children-has been documented as a trend in other advanced industrialized countries (Fussell \& Gauthier, 2005).

The transition to adulthood can be especially challenging for youths who age out of the foster care system, as recent research has documented. These potential difficulties include homelessness, unemployment and underemployment, being victims of crime and exploitation, and dependence on various types of public assistance (Dworsky, 2005; Kerman, Barth, \& Wildfire, 2004; Collins, 2001; Courtney, Piliavin, Grogan-Taylor, \& Nesmith, 2001; McMillen, Rideout, Fisher, \& Tucker, 1997). Courtney and colleagues (2001), tracking 141 Wisconsin youths in the late 1990s in their first 12-18 months after leaving custody, found that only $57 \%$ were employed, $51 \%$ had medical coverage, $27 \%$ had been incarcerated, and $12 \%$ had experienced homelessness. A study of 100 former foster youths in Nevada (Reilly, 2003) found that fully half exited foster care without a high school degree, 36\% had experienced homelessness, and $55 \%$ had no health insurance. Many (41\%) of the 
respondents reported that they did not have enough money to cover basic living expenses, with some resorting to illegal activities such as dealing drugs (24\%) or prostitution ( $11 \%)$. An earlier retrospective study of 810 youths from eight states provided some empirical support for the effectiveness of independent living services, because those who had received services generally had better outcomes (Cook, 1990, 1991 as cited in Foster \& Gifford, 2005).

To address these concerns and difficulties, Congress enacted the Chafee Foster Care Independence Act of 1999, Pub. L. No. 106-169, $\$ 477$ (1999). This legislation targets youths in state custody as well as those who "aged out" or emancipated; in 2004, there were about 100,000 youths age 16 and above in custody, and 23,000 who exited care via emancipation (Administration for Children and Families, Children's Bureau, 2006) This law improved upon previous legislation and independent living services in several ways. It allowed states to extend Medicaid coverage until age 21 to young people who have "graduated" from foster care. In addition, funding for the Independent Living Program was doubled from $\$ 70$ million to $\$ 140$ million annually, with a minimum of $\$ 500,000$ per state. States may use up to $30 \%$ of these funds for room and board for youths ages 18 to 21 who have exited foster care. The remaining funds can be used for education, vocational training, preparation for postsecondary education, training in daily living skills, substance abuse prevention, pregnancy prevention, and preventive health activities.

This study was undertaken to explore the views of current and former foster youths regarding the independent living services they received under the Chafee Act in one Midwestern state. The results can validate and empower their experience and provide insight on how policies and practices can best serve youths and their needs.

\section{Context: Kansas Independent Living Program}

As a result of the Chafee Act, new programs have been developed in Kansas and other states to provide independent living services for youths in foster care and youths who recently aged out of foster care. In Kansas, foster care and adoption services have been privatized since 1996. At the time this study was conducted, there were five contracting regional foster care agencies and one statewide adoption contractor. This extensive level of privatization of services is different from other states and has generated some level of controversy (Petr, 2004; Kansas Action for Children, 2001). One issue is the two-tiered system of administration, in which state employees ensure that state policies are implemented adequately by the private contractors.

Regarding transition to adulthood, state policy at the time of the study mandated that all youths age 15 years and above in out-of-home care receive independent living services, and that they participate in the design of their independent living plans (unless they refuse to participate). These mandates were geared toward the goal of self-sufficency. An independent living assessment is to take place and a plan developed at the first case conference after the youth turns 15 . Independent living coordinators were employed by all private contractors to facilitate appropriate programming. Foster care and adoption contractors were mandated to provide a life skills training curriculum that is outcome based. At age 16 , all youths were to be matched with an official mentor: someone who meets established qualifications and helps guide the youth toward successful adulthood. Prior to discharge from custody, contractors must conduct exit interviews and complete a form that documents the services provided.

Consistent with research that documents the contention that extended services can result in better outcomes (Kerman, Wildfire, \& Barth, 2002), there have been several voluntary programs established to provide foster youth with support during their transition from the foster care system. All of these programs are administered by the state, not by the private contractors. These programs provide up to a $\$ 400$ monthly living subsidy, tuition and expenses for postsecondary education and training, medical expenses, and transportation support. Many youths participate in more than one program.

\section{Method}

\section{Study Questions}

This study is limited in scope; it is not intended to be a comprehensive assessment of the independent living program, as a whole, but an exploratory study of youth perspectives only. Kansas Action for Children, a statewide advocacy organization, with funding from The Annie E. Casey Foundation, requested the study, which was designed to answer the following questions:

- What do foster care youths perceive as the most important issues/tasks/needs in their transition to adulthood? What are the keys to their success?

- What independent living services have been provided relative to those issues/tasks/needs identified, and from the youths' perspective, how well have they prepared them for adulthood?

- Based on the above, what are the implications for changes in program components and services that may be needed to assist foster care youth in becoming successful adults?

\section{Sample}

A convenience sample of youths was recruited through the cooperation of the state and the five private contract agencies. The regional independent living coordinators employed by the contractors were asked by the state to 
provide information about the study to youths age 16 and above whose case plans centered on independent living. Youths wishing to participate returned an initial formsigned by themselves and a parent or authorized adultto their independent living coordinator, who forwarded the form to the researcher. To recruit adult youths 18 and over who were out of state custody, a letter explaining the study and inviting the recipients to participate was sent to all former foster youths receiving a medical card under the independent living program. These adult youths expressed interest by returning the initial form directly to the researcher. The researcher received forms from a total of 38 youths. Of these, a total of 27 were interviewed: 19 in custody and 8 out of custody. The remaining 11 youths either changed their minds or did not respond to the researcher's repeated attempts to contact them. Three of the nine 18-year-old youths were still in state custody. Table 1 presents information about the sample.

Self-reported characteristics of the youth participants included: 14 male, 13 female; 15 Caucasian, 9 African American, 1 Native American, 2 Biracial; 7 age 16, 9 age 17,9 age 18,1 age 19,1 age $21 ; 6$ participants had graduated from high school and 1 had completed a GED, 2 were in college and 1 was enrolled in a postsecondary vocational technical school, 17 were attending high school, 2 were enrolled in a GED program, and 2 had dropped out of high school; 12 lived in foster homes, 3 in group homes, 1 in residential treatment, 8 with relatives (including 5 of the 8 out of custody), and 3 in an apartment/house with a friend. Time in custody ranged from 4 to 168 months, with mean of 43.1 months; the number of placements ranged from 1 to 20 , with a mean of 6.2 placements.

The sample, although not randomly selected, was generally comparable to the statewide foster care population relative to demographic variables available from the state database (Kansas Department of Social and Rehabilitative Services, 2005). In 2004, there were 8,508 children and youths in custody, of which 1,971 were age 16 and older, $51 \%$ were female, and 22\% were African American. The average number of months in custody for the 189 children who exited care due to emancipation was 44.1.

\section{Data Collection and Analysis}

A semistructured interview protocol, based on the above study questions, was developed with input from professionals representing both the state and the private contractors, from youths, and from the advocacy agency that sponsored the study. Interviews were held throughout the state, as close to the youth's residence as possible: in foster homes, group homes, mobile homes, apartments, cafés, SRS offices, and contractor offices. The author conducted all interviews in late December, 2004 and the first two months of 2005. They lasted a little less than an hour, on average, and were tape-recorded and later transcribed.
TABLE 1. Characteristics of Youths

\begin{tabular}{|c|c|c|c|}
\hline CHARACTERISTICS & $\begin{array}{l}\text { IN CUSTODY } \\
(N=19)\end{array}$ & $\begin{array}{l}\text { OUT OF CUSTODY } \\
(N=8)\end{array}$ & $\begin{array}{c}\text { TOTAL } \\
(N=27)\end{array}$ \\
\hline \multicolumn{4}{|l|}{ Age } \\
\hline 16 & 7 & 0 & 7 \\
\hline 17 & 9 & 0 & 9 \\
\hline 18 & 3 & 6 & 9 \\
\hline 19 & & 1 & 1 \\
\hline 21 & & 1 & 1 \\
\hline \multicolumn{4}{|l|}{ Sex } \\
\hline Male & 11 & 3 & 14 \\
\hline Female & 8 & 5 & 13 \\
\hline \multicolumn{4}{|l|}{ Race } \\
\hline Caucasian & 8 & 7 & 15 \\
\hline African American & 9 & 0 & 9 \\
\hline Native American & 1 & 0 & 1 \\
\hline Biracial & 1 & 1 & 2 \\
\hline \multicolumn{4}{|l|}{ Education } \\
\hline Grade 9 & 1 & 0 & 1 \\
\hline Grade 10 & 5 & 0 & 5 \\
\hline Grade 11 & 4 & 0 & 4 \\
\hline Grade 12 & 6 & 0 & 6 \\
\hline Earning GED & 2 & 0 & 2 \\
\hline High School or GED & 1 & 6 & 7 \\
\hline In college & 0 & 2 & 2 \\
\hline \multicolumn{4}{|l|}{ Living status } \\
\hline Foster home & 12 & 0 & 12 \\
\hline Group home & 3 & 0 & 3 \\
\hline Relative & 3 & 5 & 8 \\
\hline Residential treatment & 1 & 0 & 1 \\
\hline House/apartment & 0 & 3 & 3 \\
\hline \multicolumn{4}{|l|}{ Months in custody } \\
\hline Range & $4-168$ & $9-60$ & $4-168$ \\
\hline Mean & 47.7 & 32.5 & 43.1 \\
\hline Median & 48 & 31.5 & 38 \\
\hline \multicolumn{4}{|l|}{ Months out of custody } \\
\hline Range & & & $1-37$ \\
\hline Mean & & & 10.75 \\
\hline Median & & & 9 \\
\hline \multicolumn{4}{|l|}{ Number of placements } \\
\hline Range & $1-20$ & $1-18$ & $1-20$ \\
\hline Mean & 6.5 & 5.5 & 6.2 \\
\hline Median & 4 & 3.5 & 4 \\
\hline
\end{tabular}

In four interviews, it was soon after discovered that the tape-recorder had malfunctioned, so these interviews were reconstructed over the phone shortly after the faceto-face interview. Most of the youths (16) were interviewed individually; 8 youths were interviewed in pairs; 3 other youth were interviewed together. Participants were paid $\$ 25$ at the end of the interview.

This stipend was intended in part to convey respect for the young person and to underscore that their participation was valued. The researcher attempted to convey this respect in other ways as well, such as meeting with participants on their own turf, explaining that the study was sponsored by an independent advocacy organization that requested that only youths themselves be interviewed (not professionals or parents), by asking introductory questions about their background and interests to help put them at ease, and by not having them fill out forms or surveys. 
Transcribed interviews were analyzed using Atlas ti, a software program designed to analyze qualitative data. The process consisted of coding units of interview text (youths' responses to questions) according to the theme(s) represented, then organizing these coded statements so that common themes across participants could be ascertained.

\section{Results}

The following vignettes present two contrasting accounts of independent living services and their effects. These stories serve to anchor the two ends of the continuum of experience. Other situations fall somewhere between these extremes. (Both subjects gave permission for details of their experience to be shared and approved the text below.)

\section{A.'s Story}

A.'s situation is notable because it represents the best of what foster care has to offer older youth. Her situation demonstrates how a devoted foster parent and competent, conscientious workers can have a positive, lifechanging impact on a young person's life: "I figure that, my whole foster care experience, I figure if I hadn't come into foster care, I would be somewhere on welfare, pregnant, in a trailer. It's like foster care saved my life."

A., now 19 years old and a freshman in college, entered state custody at 14 due to a combination of longstanding physical and verbal abuse from her parents and behaviors such as taking drugs and not attending school. The first 2 years in foster care were characterized by ups and downs in various group homes and foster homes. At her fifth placement, A. literally found a home. As she describes it, her foster mother (K.) seemed to understand her needs and refused to give up on her, despite serious behavioral challenges on A.'s part. K.'s capacity for understanding was immediately demonstrated when A. first arrived at the placement-angry, hostile, and missing her friends:

\footnotetext{
It was a foster home. I came in and I was so mad, like I didn't want to be there, I didn't want to talk to anybody, I just wanted to sit in my room and be left alone. And, I wanted to call my friends back in [previous location]. Well, I think my foster mom understood that I needed that time to be by myself. So, she gave me her cell phone and said call your friends. And come out when you're ready. And, I called, I think I talked on the phone for 3 hours, ran up her bill big time. Then I came out and she's like, do you need help unpacking anything? Are you hungry? Do you want to go out and eat? I'm like, yeah sure.
}

In addition to this keen awareness of and respect for A.'s needs, $\mathrm{K}$. and the case manager refused to give up on her. She and K. would get into serious conflicts, but would get competent help from the case manager, who would "be there in 10 minutes."

We got into some pretty monstrous fights and she would never let me leave. I kept telling her I want to go I want to go, and she was like, you're going to deal with it. I was lucky enough to get the people that weren't going to say, "we're going to quit helping you because you don't want our help."

I had a bunch of people that were too stubborn to give up. Just they kind of grew on me like I'd always like push them away and like go away, go away, but they wouldn't give up and I had the attitude that I wanted somebody to help me in the end, I wanted people to be there.

Today, A. reports that she has a "wonderful support system." She remains in close contact with $\mathrm{K}$. who is planning to adopt her. Her current independent living coordinator keeps in regular contact: "She's like, if I ever need anything, I have her home number, her pager, I have her cell phone number. If I ever need anything, she's like, just call me."

A. has a community mentor who meets with her regularly, has helped her move twice, and gives her information about budgeting. A. also has made a number of steadfast friends at college, and keeps in touch with her siblings and cousins.

The result is that $\mathrm{A}$. is confident about her future and feels very prepared to accomplish her goals. A. lives off campus in a house with roommates. She works on campus 25 hours a week. Her goals are to obtain a degree in criminal justice/law enforcement, work as a police officer while going to law school, and practice law for a few years before becoming a juvenile court judge. A. is very appreciative of all the postcustody benefits she receives-medical card, tuition waiver, educational and training vouchers, and living subsidy. "The system has helped me so much. They put me on my feet."

\section{C.'s Story}

In sharp contrast to A.'s story above, C.'s situation represents what can happen when "the system" does not provide adequate help and support to young persons in foster care. C., now 18 and out of state custody, is struggling to make ends meet, to obtain a job, and to complete his GED after dropping out of high school. When asked how prepared he felt to be independent, C. replied:

I'm not ready because I ain't got a job yet. I haven't got any type education yet. So, that's kind of one of the reason why I think places really don't have me because I don't have any skills or any education. 
C. was placed in state custody at age 13 , just a few months after he moved to Kansas to live with his grandmother. The move was prompted by the death of his father who had raised him alone; he never knew his mother. He was placed in foster care because of truancy and because "somebody said I was using drugs."

During his almost 5 years in state custody, C. lived in at least 9 different placements, including youth shelters, group homes, residential treatment, and foster homes. C. spoke highly of two of his foster homes, especially one where he stayed a year and a half; he still maintains contact with the foster dad. C. said that his current struggles can be traced to not finishing high school. When he began his last foster home placement, at age 17, the local high school was going to place him in the eighth grade due to lack of credits from so much moving around. He went to school at all his group home placements, but somehow the credits didn't count.

When I moved to the foster home, they tried [to enroll me in school], but the placements I went in, I guess the credits didn't count because they were just like you had divide them separately or something like that so they didn't add them credits.

Q: So the school wouldn't even accept you? C.: "Oh, they would have, but I would have been, since of the placements, I would have been back in eighth grade."

C. reported that he has never had an independent living coordinator, and that the only preparation for independent living that he had was from foster parents who helped him learn how to cook and learn other "life skills" such as money management. He does have a medical card, but said that no one has ever talked to him about potential benefits such as a tuition waiver or independent living subsidy.

That's what I was talking to my caseworker about, too. When I turn 18, would there be a possibility I can at least get my own one-bedroom apartment or a HUD house or something? She goes, "Oh, I'll send you information about it."

Despite the struggles, C. still has hope for the future. He plans to enroll in the next GED class offered in his community. After passing the GED, he wants to join the Army and train to become an engineer who works on tanks and trucks. His support system consists of his girlfriend, a male friend, and his former foster parent in another community. When asked what the system could have done differently, C. stated,
I think case workers should hear the kids' voices when they ask for [help]. That's what I think. That would help the kids out and if they are actually be heard, that would help them out a lot.... She wasn't there when other kids needed her or when I needed her or other foster homes needed her.

The experiences of the remaining 25 participants generally fell somewhere between the extremes of the two presented scenarios. The results will be discussed in aggregate form, with common themes reported, using individual quotations to illustrate those themes.

\section{Youth Perceptions of Most Important Transition Issues}

Almost all youths seemed to understand the skills and behaviors that were necessary to become successful adults. They emphasized getting a good education and a good job. They also stressed assuming adult responsibilities such as cooking, managing money, and maintaining housing and transportation.

I see grown adults walking around, like not doing anything with their life, I think it's unnecessary. At some point in they life, they messed up somewhere. I think to myself, I don't want to be like that one day. So, I try to stay on track at school and stuff.

I don't think your age makes you an adult, you know? Like for instance, being a man, you know, being a man is [meeting your] responsibilities, you've got to learn from your mistakes, you know what I'm saying, that's what growing up is being about.

It takes a lot of hard work. You have to have technical skills. Communication. You have to be good on your problem solving and everything like that.

In addition to knowing necessary skills and behaviors, almost all the youths anticipated that becoming a successful adult was going to be a hard process for them, especially finishing their education, managing money, and staying away from bad influences such as alcohol, drugs, and harmful peers.

You have to want to it. You have to really fight for it.

Because, it's not just going to be given to you.

As mentioned previously, the vast majority of youths in this study were refreshingly optimistic about their own vocational and educational futures. They aspired to a wide range of occupations such as teacher, social worker, auto mechanic, beautician, cook, doctor, lawyer, nurse, computer technician, police officer, graphic designer, soldier, actress, underwater welder, clothing designer, and custom auto body painter. 
For the most part, most youths also seemed to know what steps were necessary to achieve their goals.

One, I want to finish college. And I want to major in business because the next 10 years I see myself, I'm going to have my own clothing line.

My future, I want to go to a technical school for auto mechanics. I want to be a auto mechanic. And, hopefully, if I get to that point, and I get all that stuff together, I want to open up my own shop, be entrepreneur, you know.

Two of the young women in custody were already parents of young children, and one who had exited custody was newly pregnant. All of the other youths were unanimous in their desire and determination to postpone marriage and parenthood.

I do know that I want to get married and have kids. I'm just not ready for it yet.

\section{Youth Perceptions of Independent Living Services Received}

The youths in this study, especially those still in custody, were generally satisfied with the independent living services they were receiving or expected to receive. The focus of youths in custody tended to be on completing their high school educations; preparation for future vocation was seen as something that occurred at the postsecondary level, with help from the postcustody benefits such as the tuition waiver and independent living subsidy. For youths out of custody, those without jobs and not in training or college programs ( 5 out of 8 youths) tended to be less satisfied, expressing that the services they received while in and out of custody had been either inadequate or nonexistent.

A more focused look at the actual services provided to youths in custody does not necessarily seem consistent with the reported high level of satisfaction. Many youths did not receive the various types of independent living services that were established by state policy. Here, the discussion will focus on education, mentors and support systems, life skills training, vocational preparation, and knowledge of postcustody independent living benefits.

Education. Most of the youths reported that they were doing well in their educational progress, but 7 youths (26\%) reported being seriously behind in their educational progress and goals. These 7 had experienced numerous placements while in custody and attributed their poor educational progress to factors related to the frequent moves.

It's hard to move around so much because you get so behind on your schooling. I'm supposed to be in 11th grade, but I'm only in 9th grade.
The experience of C., depicted earlier, who dropped out of high school rather than being placed in the eighth grade at age 17 , is a graphic example of what can happen. Another young man who reported 12 placements in 4 years is now enrolled in a GED program:

I started doing GED last year towards the end of school because my high school, with my creditwise, I'm a freshman, but my agewise, I'm supposed to be a senior. So, I didn't think I could make that up, so I just opted for a GED.

A 17-year-old female, who moved numerous times in 5 years of custody, now thinks she is in the 10th grade, but she is confused.

In the record they have me as a 10th grader. Because that's the last year that I completed.... I'm a senior but they say that, I don't know, they got, all my records are really mixed up.... I just go to school because I know I'm supposed to be in school.

With all these placement moves, it would be difficult to keep on track with schooling, even if the system were well prepared to deal with the problem. According to these youths, the problem is serious and is not being addressed well by the system. One factor reported by the youths was the poor quantity and quality of the education provided at group homes and shelters. They reported that they took only one or two "serious" subjects a day, were often grouped with children of wide-ranging ability, and were not challenged with material appropriate to their level. Another factor is that local public school districts reportedly do not accept credits that youths think they have earned at these facilities. A prime example of this was C.'s situation, reported above. He was 17 , and had been in only the 10th grade at his previous facility, but the local school district at his new foster home was going to place him in the eighth grade. He dropped out of school instead and is not yet enrolled in a GED program.

Mentors and support systems. Young people need supports to assist in the transition to adulthood. To assist foster care youth, many of whom do not have strong family support, the state requires that youths age 16 and above be matched with a mentor. As discussed earlier, state policy required that a mentor be designated for each young adult in custody, but of the twenty-seven youths in the study, only $11(41 \%)$ were able to identify an adult who served as a mentor. In some of these situations, the mentor was highly valued by the youth.

Oh, my mentor ... that's my foster parents' daughter. $\mathrm{Me}$ and her are real close, we always have been since I very first met them. When their family gets together like on Fourth of July and stuff, they always invite me 
over. She just, she's going to help me with splitting my money up and saving and stuff like that so I can pay my bills and still have left over money.

I go on pass with her every other weekend.... I play with her son and they got a video game over there. I cook over there sometimes. I actually cook a lot over there.... I met her at another school. She was like my educational advocate.... I love that lady to death.

Some of those who did not have a mentor thought it would be a good idea, wheras others did not believe they would be of much help.

So, to just have someone you could talk to and count on, I think that would help a lot of kids because that's what a lot of kids need. I need it myself.

I guess I have one but I don't feel like I need one so I really don't talk to him.

When asked about support persons other than mentors, some youths were able to identify family members, current and former staff and foster parents, and/or other people in the community. Many of the youths in custody planned to live with family after exiting custody, and 5 of the 8 already out of custody were living with relatives.

One important way that these persons provided support was the verbal encouragement of youths and expressions of confidence in their abilities.

My grandparents and former foster parents have supported me, saying that I can do it. Just staying on top of it and helping me when I need help. I appreciate that a lot. It helps a lot.

Another important form of support was being available to listen and provide quiet guidance.

Pretty much my brother helps me and guides me so I don't make the same mistakes he did.

I probably really have got help is probably from my pastor because he talks to me about a lot.

About an equal number were unable to identify any persons who served as supports, with some of these saying they didn't need anyone because they could do it on their own. Others lamented the lack of support, especially the lack of family to fall back on.

I don't know. I got the guy upstairs. I don't really need nobody else.

Because it's just me. I don't have, you know, financial help. I don't have family like that to help me, like you know, my immediate family, mostly everybody has died off. I have aunts. Okay. I have two aunts. I have cousins. But you know, I mean, they have their own family ahead and they're so much older than me.

Life skills training. State policy required that contractors provide a life skills curriculum that is outcome-based. This training typically covered many of the eight independent living skill areas outlined in the state policy manual. Seven of the youths (26\%) said that they had not received any life skills training, and 2 of these said it had been offered, but they refused. Many of those who had received the training said that they had attended such a class at a regular school setting, a mental health agency, or in a group home facility. Several said that their foster parents were teaching them these skills on a less formal basis, day-to-day.

Those who had received the classes gave them a mixed review: some said they had learned a lot, whereas others said that they were boring or that they already knew the material.

They just went over basically everything you need to know. That helped me a lot. I learned the most out of those classes.

It was boring. They really wasn't telling me nothing. I already know how to cook. I mean, I know the basics.

Vocational preparation. Seven (37\%) of the 19 youths in custody, and $3(38 \%)$ of the 8 out of custody, were working at paid jobs in the community. Of these latter 3, 2 were working part-time while attending college, and the third worked only about 4 hours per week. Youths in custody tended to work typical teenage, part-time jobs such as waitresses in food service. One worked in a retail supply store and 1 as a youth supervisor. Youths in custody were not, as a group, dissatisfied with the availability of vocational preparation services. They tended to see that as something that was done after custody and after they completed high school. A few of the youths in custody wanted to work, but were struggling to find suitable employment.

It's just so discouraging when you just be out there searching and searching for a job and it seems like nothing ever turns up. You pray, you go to church and you try to do the right thing, you see these young teenagers on the corner, selling drugs and ... making more money that what you do.

Knowledge of postcustody independent living benefits. Nineteen $(70 \%)$ of the 27 youths in this study knew about the benefits that they qualified for after turning 18 and exiting SRS custody. The remaining 8 were not informed about such benefits. 
Whenever I turn 18 or whenever I go to college, they'll pay for my college as long as it's in the state of Kansas. So, that really helps me out. Yeah, once I turn 18 , too, I get $\$ 400$ a month subsidy. So, another thing that will help me out a lot with, maybe I won't have to work so much hours, cut it down.

The youths who knew about benefits generally were enthusiastic about the prospect of the benefits, which seemed to infuse them with hope and optimism about their futures.

\section{Basically, it was like, you want to do something, we'll help you. Nobody ever came acting like that so it was like, all right, I'll take advantage of it. Give me your money. I'll go to college with it. So basically, that's the main thing. If they never said that, I probably would just, wouldn't even be in this meeting today; I would have got released when I turn 18 and picked up where I left off at. Yeah. It helped me a lot.}

The 8 youths who were out of custody provide a portrait of the range of experiences with postcustody benefits. Two of these youths were in college, utilizing all of the benefits, and doing well. One young man had just turned 18 the previous week and had moved out of his foster home to live with his biological mother and grandparents. He was in 11th grade and starting a new high school, and looked forward to receiving postcustody benefits to support his living expenses, and later, his college tuition. Five out of the 8 not in custody were unemployed, not enrolled in any postsecondary education, and not receiving any postcustody benefits except the medical card. Three of these 5 youths said they had not had an independent living coordinator while in custody and did not know about the benefits available to them, except through word of mouth from other foster youths. The other 2 had been told about potential benefits but had lost contact with workers. All 5 seemed confused and unsure about whom to call or what to do to apply.

\section{Summary and Implications}

Several limitations should be noted. First, this is not a comprehensive study of independent living services. Only youths were interviewed, and their perspective is only one view of reality that may or may not coincide with other important perspectives such as those of parents, foster parents, group home staff, SRS workers, and private contractors. Second, because the sample was small and not randomly selected, the sample youths may or not be representative of the whole. Finally, time and resource constraints mitigated against conducting member checks and other procedures that could have enhanced the data analysis (Anastas, 2004).
The overall results paint a mixed portrait of the utilization and perceived effectiveness of independent living services. Many youths identified positive aspects of the independent living services they received; others seemed uninformed or less satisfied. On the positive side, the postcustody benefits program was uniformly endorsed as providing an excellent foundation of financial and other supports to assist foster care youth in their transition to adulthood. Those youths still in custody anticipated these benefits with hope and excitement. Those receiving the benefits were very appreciative. Most youths were generally satisfied with independent living services that they were receiving. All youths valued their education and most reported making good educational progress. Almost all of the youths were optimistic about their futures despite abusive histories, numerous foster care placements, and estrangement from biological families.

The study also identified several more problematic areas deserving further investigation and remediation. First, not all of the youths received the mandated independent living services while in custody. Second, youths who experienced several placements in facilities such as shelters, youth ranches, group homes, and residential treatment were at high risk for educational delay and failure. The problem reportedly exists both with respect to the educational programming at the facilities and in the policies of local school districts. Third, many youths, both in and out of custody, lacked mentors and viable support systems. State policy recognizes this need of youths in transition, but building and realizing that support appears to be a difficult task in many cases. Some youths in custody had the attitude that they want to (or have to) do it on their own; some youths recently out of custody appeared to be floundering. Fourth, some youths who had exited SRS custody wanted to receive postcustody benefits, but were not receiving them. Upon exiting custody, they did not immediately begin to receive the benefits, and they didn't seem to know how to apply or whom to talk to.

State records indicate that this experience is shared by others. Whereas 189 youths exited care via emancipation in the previous fiscal year alone, only 50 youths out of custody at age 18-21 received the medical card benefit, and only 109 received a living subsidy. The roots of this problem may be structural, because the private contractors are not responsible for any services after the youth exits custody. Thus, the system must transfer the youth's case from the private contractor and the professionals that the youth knows to some new worker in public child welfare system at the moment of aging out. To be successful, this process requires advance planning and close coordination prior to the 18th birthday. After the youth exits custody, aggressive outreach and follow-up on the part of the new worker are essential to maintain contact with the youth and provide access to the flexible array of supports that may be necessary as the youth's needs and interests evolve and change. 
This study of the perspectives of foster youth demonstrates the potential value of independent living services and identifies certain aspects for further attention and possible action. First, because of the subjects' strong and unanimous endorsement of postcustody supports, consideration should be given to continuing and expanding postcustody benefits for youths who exit foster care as adults, while ensuring that all youths in and out of custody receive the services for which they are eligible. Second, focused efforts in the form of educational ombudsmen and joint education/child welfare task forces may be necessary in order to monitor and improve educational programming for youths in foster care who experience multiple placements. Third, it should be recognized that the development of social supports is often a difficult process that is sometimes resisted by youths. Thus, the process should involve not only the development of mentors but also should aggressively engage extended family members. Like other studies of foster youth (Courtney, et. al. 2001; Courtney \& Barth, 1996), many of the youths in this study who exited or were about to exit custody relied heavily on family members for support, even when parental rights had been terminated. In this regard, foster youth are similar to the larger population in that the current trend among young adults in the United States and other industrialized countries is toward a prolonged transition to adulthood characterized by prolonged dependence on family (Foster \& Gifford, 2005) Yet, current services presume that emancipated foster youths will live independently (thus, the title "independent living" services). Because many youths plan to live with relatives after exiting custody, it behooves policymakers and workers to anticipate and plan for this possible eventuality by equipping families to better support youths, even when parental rights have been severed.

\section{References}

Administration for Children and Families, Children's Bureau. (2006, July). The AFCARS report: Preliminary FY 2004 estimates as of June 2006. U.S. Department of Health and Human Services, Administration for Children and Families. Retrieved November 1, 2006 from http://www.acf.hhs.gov/programs/cb/stats_research/ afcars/tar/report1l.htm

Anastas, J. W. (2004). Quality in qualitative evaluation: Issues and possible answers. Research on Social Work Practice, 14, 57-65.

Arnett, J. J. (2000). Emerging adulthood: A theory of development from the late teens through the twenties. American Psychologist, 55, $469-480$.

Collins, M. E. (2001). Transition to adulthood for vulnerable youths: A review of research and implications for policy. Social Service Review, 75, 271-291.

Cook, R. (1990). A national evaluation of Title IV-E foster care independent living programs for youth: Phase 1 final report. Rockville, MD: Westat.
Cook, R. (1991). A national evaluation of Title IV-E independent living programs for youth: Phase 2 final report. Rockville, MD: Westat.

Courtney, M., \& Barth, R. (1996). Pathways of older adolescents out of foster care: Implications for independent living services. Social Work, 41, 75-83.

Courtney, M., Piliavin, I., Grogan-Taylor, A., \& Nesmith, A. (2001). Foster youth transitions to adulthood: A longitudinal view of youth leaving foster care. Child Welfare, 80, 685-717.

Dworsky, A. (2005). The economic self-sufficiency of Wisconsin's former foster youth. Children and Youth Services Review, 27, 1085-1118.

Foster, E. M., \& Gifford, E. J. (2005). The transition to adulthood for youth leaving public systems: Challenges to policies and research. In R. A. Settersten, Jr., F. F. Furstenberg, Jr., \& R. G. Rumbaut (Eds.), On the frontier of adulthood: Theory, research, and public policy (pp. 501-533). Chicago: University of Chicago Press.

Fussell, E., \& Furstenberg, F. F., Jr. (2005). The transition to adulthood during the twentieth century: Race, nativity, and gender. In R. A. Settersten, Jr., F. F. Furstenberg, Jr., \& R. G. Rumbaut (Eds.), On the frontier of adulthood: Theory, research, and public policy (pp. 29-75). Chicago: University of Chicago Press.

Fussell, E., \& Gauthier, A. H. (2005). American women's transition to adulthood in comparative perspective. In R. A. Settersten, Jr., F. F. Furstenberg Jr., \& R. G. Rumbaut (Eds.), On the frontier of adulthood: Theory, research, and public policy (pp. 76-111). Chicago: University of Chicago Press.

Kansas Action for Children. (2001). The Kansas child welfare system: Where are we now? Where are we going? Topeka, KS: Author.

Kansas Department of Social and Rehabilitative Services. (2005). Portraits: A data album of families served through children and family services, FY 2004, Year End. Topeka, KS: Author.

Kerman, B., Barth, R. P., \& Wildfire, J. (2004). Extending transitional services to former foster children. Child Welfare, 83, 239-253.

Kerman, B., Wildfire, J., \& Barth, R. P. (2002). Outcomes for young adults who experienced foster care. Children and Youth Services Review, 24, 319-344.

McMillen, J. C., Rideout, G. B., Fisher, R. H., \& Tucker, J. (1997). Independent living services: The views of former foster youth. Families in Society, 78, 471-479.

Petr, C. G. (2004). Social work with children and their families: Pragmatic foundations (2nd ed.). New York: Oxford University Press.

Reilly, T. (2003). Transition from care: Status and outcomes of youth who age out of foster care. Child Welfare, 82, 727-746.

Settersten, R. A., Jr., Furstenberg F. F., Jr., \& Rumbaut R. G. (Eds.). (2005). On the frontier of adulthood: Theory, research, and public policy. Chicago: University of Chicago Press.

Christopher G. Petr, $\mathrm{PhD}$, is professor, University of Kansas School of Social Welfare. He is author of Social Work with Children and Their Families: Pragmatic Foundations, published by Oxford University Press. Correspondence regarding this article may be sent to chrisp@ku.edu or University of Kansas, School of Social Welfare, 102 Twente Hall, Lawrence, KS 66045.

Author's note. This study was funded by Kansas Action for Children.

Manuscript received: September 19, 2005

Revised: July 13, 2006

Accepted: August 22, 2006 